\title{
Isolation, characterization and production of a new recombinant lectin protein from leguminous plants
}

\author{
Ayyub Patel \\ Correspondence: astricword@gmail.com

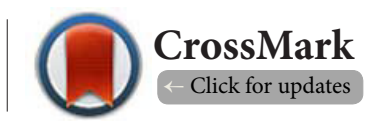

Department of Clinical Biochemistry, College of Medicine, King Khalid University, KSA, Saudi Arabia.

\begin{abstract}
Lectins are present in microorganisms, plants and animals and have attracted great interest due to their varied physiological roles in cell agglutination, anti-tumour, immunomodulatory, antifungal and antiviral effects. Legume lectins are important to the pharmaceuticals but they are produced in low amounts in the plant seeds. Moreover, the genes controlling these proteins are conditionally active, i.e., they work under specific circumstances and not in regular manner. Looking into these limitations, we aimed this work to produce a recombinant lectin for pharmaceutical use especially for the treatment of cancer. Three different legume plant species were collected from Aseer region of Kingdom of Saudi Arabia viz., Acacia seyal, Pisum sativum (wild type) and Pisum sativum (Pea). The plant tissues were subjected to RNA extraction, the extracted RNA was used for lectin gene amplification using specific primers. Cloning, subcloning of the Acacia 400bp gene was carried out and in vitro transcription, combined with protein purification was undertaken. The cytotoxicity of the recombinant lectin was performed on two cell lines such as breast cancer MCF-7 and liver cancer HepG-2 cells. Our study resulted in the observation of two amplicones with all the three examined species, the amplicone molecular sizes were 800 and $400 \mathrm{bp}$. The $400 \mathrm{bp}$ amplicone was excised from the agarose gel, purified and sequenced. The sequence analysis revealed that the nucleotide sequence belongs to lectin gene. The sequence analysis revealed that the lectin gene isolated from Pisum sativum (wild plant) is similar to the Pisum sativum lect1 with identity 90\%, whereas, lectin isolated from Pisum (pea) showed similarity of $91 \%$ with the other lectins. On the other hand, Acacia lectin showed similarity with Lotus japonicus nod factor binding lectin gene with identity of $95 \%$. Thus we conclude that new lectin protein of 17 and $15 \mathrm{kDa}$ was produced that can be used by pharmaceutical industries.
\end{abstract}

Keywords: Legumes, acacia seyal, Pisum sativum, lectin, protein purification, cloning

\section{Introduction}

Acacia is an important plant genus that is commonly used in a variety of infections. It is widely distributed in Asia, Australia and America and efficacy has been demonstrated in the treatment of gonorrhea, leucorrhoea, diarrhea, dysentery and wounds [1]. Lectins are a well-known family of cationic antibacterial peptides (AMPs) isolated from fungi, plants, insects, mussels, birds and various mammals [25]. Lectins with different carbohydrate specificity have been isolated from forty nine different species, primarily from seeds. Lectins are the most abundant proteins (20-25\% of total soluble proteins) in the park of several legume trees such as Robinia pseudoscacia and Maackia amurensis. Plant lectins have great potential as tools in the identification, purification, and stimulation of specific glycoconjugates. They also have been widely used to distinguish between cell types $[5,10]$. Lectins are also found in microorganisms, plants and animals and have attracted great interest due to their varied physiological roles in cell agglutination [13], anti-tumour [15,16], immunomodulatory [22], antifungal [12] and antiviral effects [29]. Furthermore, lectin-mediated drugs have been acquired to target specific cells and some lectins with anti-proliferative properties were isolated and characterized from different parts of the plant, like; seeds [14], leaves [19] and roots [27,31].

It is reported that the total proteins from pinellia pedatisecta obviously inhibited ovarian cancer cell lines but showed no toxicity to human umbilical cord blood hematopoietic progenitor's in vitro [8,27,32]. It is also reported that the $30 \%$ $\left(\mathrm{NH}_{4}\right)_{2} \mathrm{SO}_{4}$ deposition part of total proteins from Pinellia ternata rhizome could significantly inhibit human hepatocellular carcinoma cell line Bel-7402 growth and induce its apoptosis $[8,24]$. Succeed to isolate lectin like protein from Acacia farnesiana and they found that the isolated lectins protein sequence showed that AFAL has $68 \%$ and $63 \%$ sequence similarity with lectins of Phaseolus vulgaris and Dolichos biflorus, respectively.

Lectins with different carbohydrate specificity have been isolated from forty nine different species, primarily from seeds. Lectins are the most abundant proteins (20-25\% of total soluble proteins) in the bark of several legume trees such as Robinia pseudoscacia and Maackia amurensis. Plant lectins have great potential as tools in the identification, purification, and stimulation of specific glycoconjugates. They also have been widely used to distinguish between cell types. 
Ayyub Patel, Biochemical Compounds 2014,

Recent and modern studies on these plants proved the occurrence of active principles in their different organs. Their pharmacological activity has been investigated. In view of their importance as a source of extracts and active constituents used in medicine, they were embodied in different pharmacopoeias. The collection of these plants from their natural habitats threatens them to a great measure. No means have been taken up till now to conserve these wild plants. In view of the rising demands for these plants and the limited amount of the wild supply, it is indispensable to undertake measures for their conservation for the sake of treatment of various diseases. A great deal of work has been conducted over the last half century to screen plant resources for unknown lectins and to characterize their carbohydrate specificities. Furthermore, as a result of recent developments in structural biology, much has been learned about the molecular basis of carbohydrate recognition by lectins. The general principles derived from studying the early structures have now been confirmed many times. It appears that legume lectins consist of a conserved scaffold composed of a basic set of essential and conserved residues, among which occur a limited number of variable residues that direct the specificity of the lectin.

Many reports have been published ascribing pharmacological roles/clinical effects to plant derived lectins. Vescum album lectin had an inhibitory effect to tumor cells and reduced the number of tumor cells in lungs of mice injected with B16F10 cells; wheat germ lectins had potential as an adjuvant in the therapy of malignant neoplasia and other diseases caused by or following immune deficiency; mushroom lectins inhibited growth of sarcoma cells in the peritoneal cavity and exhibited clearly prolonged life-spans; mistletoe lectins were found to have anti cancer and immunomodulating effect in HIV- positive patients. Legume lectins are important to the pharmaceutical industry and in the treatment of many human ailments. Lowering of cost of production of lectins and increasing their activity and clinical effectiveness would be very valuable to the pharmaceutical industry and, potentially, in cancer and HCV treatments. Novel lectins found in medicinal plants could hold great promise in that respect. Additionally, modern methods of biotechnology, genetic engineering could hold the key to improving the potency of these proteins. Work on cloning novel lectins from medicinal plants in arid regions and transfer cloned gene to $E$. coli to produce these lectins without altering their tertiary structure is also lacking. Production systems utilizing cell-suspension cultures could greatly facilitate cost- effective production of this bioactive protein for pharmaceutical interests. Finally, testing the effectiveness of recombinant protein (Lectin) in cancer treatment and inhibition of viral growth is a very promising aspect in its medicinal and Pharmaceutical applications.

The present work is an attempt to give a multidisciplinary study on these plants covering their taxonomy, ecology, phytochemistry, pharmacology...etc. and finally produced a recombinant organism able to produce high amounts of lectin compound in active form.

\section{Materials and methods \\ Plant collection}

Different legume plant tissues were collected from different areas in Aseer region of Saudi Arabia, but three different species were selected; Acacia (2 species), Pissum (Wild pea) and pea as cultivated plants. The collected young leaves and buds were washed with tap water, dried and then kept in aluminum foils and stored at $-80^{\circ} \mathrm{C}$ until use. The Acacia tissues were used as a genetic pool, the tissues were ground as one sample (Figure 1).

\section{RNA isolation protocol}

Total RNA was extracted from the plant tissues using Qiagene RNA extraction kit (Qiagene comp, Germany). There are two

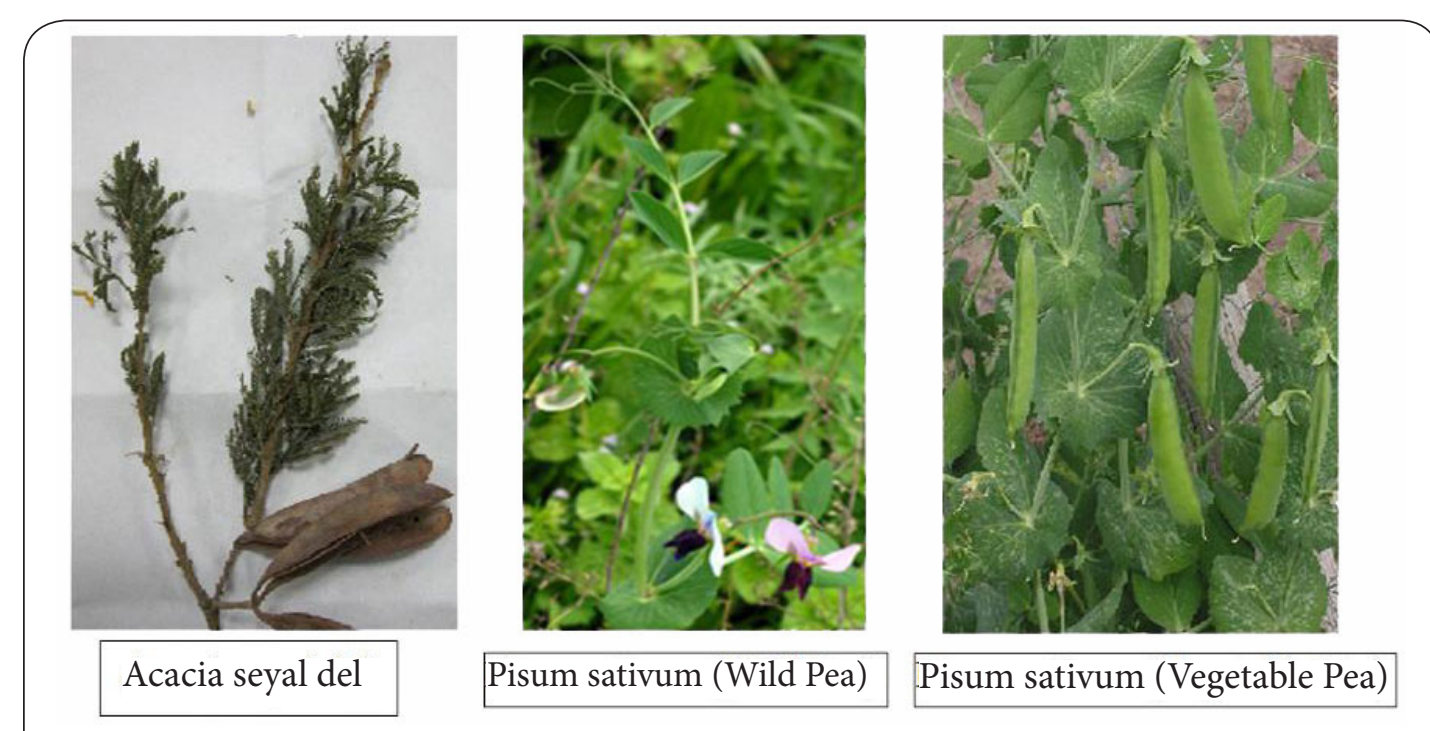

Figure 1. Photographs showing the three selected plants, collected from Aseer region. 
species of Acacia found in Aseer, so genetic pool from these two species was made. $0.1 \mathrm{gm}$ of the frozen tissues was minced in liquid nitrogen using mortar and pestle in the presence of buffer ( $100 \mathrm{mM}$ Tris- $\mathrm{HCl}, 0.2 \%$ lysozyme and $0.1 \%$ glucose). The extraction process was performed according to the manufacturer procedure and the extracted RNA was resuspended in $100 \mu \mathrm{L}$ of Diethyl pyrocarbonate (DEPC) water. In case of acacia the above mentioned methods did not give a high yield of RNA due to the high polysaccharides content in acacia tissues. So, we used CETAB (Cetyltrimethylammonium bromide) method to diminish the polysaccharide from the extract and then the extract was completed using Qiagene for RNA extraction kit (Qiagene, Germany).

Reverse transcription of RNA: Reverse transcription reactions were performed using oligo (dT) primer. Each $25 \mu$ reaction mixture containing $2.5 \mu \mathrm{l}$ ( 5 x buffer with $\left.\mathrm{MgCl}_{2}\right), 2.5 \mu \mathrm{l}(2.5 \mathrm{mM}$ ) dNTPs, $1 \mu \mathrm{l}(10 \mathrm{pmol})$ primer, $2.5 \mu \mathrm{l}$ of plant extracted RNA and $0.2 \mu \mathrm{l}$ reverse transcriptase (MLVR, Fermentaz Company). PCR amplification was performed in a thermal cycler (Eppendorf) programmed at $95^{\circ} \mathrm{C}$ for $5 \mathrm{~min}, 42^{\circ} \mathrm{C}$ for $1 \mathrm{hr}, 72^{\circ} \mathrm{C}$ for $10 \mathrm{~min}$ (Enzyme inactivation) and stored at $4^{\circ} \mathrm{C}$ [7].

\section{Lectin DNA amplification using specific PCR}

The synthesized CDNA of each plant was subjected to PCR amplification using the specific primers of lectin gene according to [17]. PCR amplification was carried out for each plant in separate manner in total volume of $25 \mu$. The reaction conditions are showed as follows: $2 \mu$ l of (100 ng CDNA), $0.2 \mu$ l of $10 \mu \mathrm{mol}$ each primer (forward 5'-TCAACGAAAACGAGTCTGGTG-3' and reverse $5^{\prime}$ - GGTGGAGGCATCATAGGTAAT - $3^{\prime}$ ), $2.5 \mu \mathrm{l}$ 10x PCR Buffer, $2.5 \mu \mathrm{l}$ of $(2.5 \mathrm{mM})$ dNTPs, $0.3 \mu \mathrm{l}$ of $1 \mathrm{U}$ Taq DNA polymerase (Qiagene, Germany). The program was initiated for 5 min of denaturation, followed by 10 cycles of amplification with denaturation for $15 \mathrm{sec}$ at $94^{\circ} \mathrm{C}$, first annealing for $20 \mathrm{sec}$ at $55^{\circ} \mathrm{C}$ and an extension at $72^{\circ} \mathrm{C}$ for $15 \mathrm{sec}$ and followed by 40 cycles of amplification with denaturation for $1.5 \mathrm{~min}$, second annealing for $1.5 \mathrm{~min}$ at $53^{\circ} \mathrm{C}$, an extension at $72^{\circ} \mathrm{C}$ for $1 \mathrm{~min}$ and a final extension at $72^{\circ} \mathrm{C}$ for 5 min on Eppendorf thermal cycler.

\section{DNA sequencing and accession number}

The PCR product (400bp) was excised from the agarose gel using agarose DNA extraction kit, (Qiagene, Germany) and then the purified DNA was subjected to DNA sequencing (MACROGEN, Korea) using the designed forward primer in the sequence reaction. Sequence analysis using CLUSTAL W program were performed. The nucleotide sequences were analyzed with the BLAST database (www.ncbi.nlm.nih.gov) and the DNA sequence was submitted into the GenBank under accession numbers (JQ964105, JQ964106 and JQ964107).

\section{Cloning and subcloning lectin gene}

Cloning of amplified PCR products was done by T/A based cloning protocol by using TOPO TA Cloning ${ }^{\circledR}$ (with $\mathrm{pCR}^{\circledR}$ 2.1 $\mathrm{TOPO}^{\circledR}$ Cloning vector) and (a TOP $10 \mathrm{E}$-coli strain) (Invitrogen ${ }^{\mathrm{TM}}$,
USA). The recombinant bacteria were examined using Blue/ White colony analysis. The well characterized clone were subjected to digestion using $\mathrm{BamH} 1$ restriction enzyme to release the gene from the $\mathrm{pCR}{ }^{\circledR}$ 2.1-TOPO ${ }^{\circledR}$ vector, meanwhile the released fragment was purified by EzWay ${ }^{\mathrm{TM}} \mathrm{Gel}$ Extraction kit (Kombiotech comp, Korea) and legated to the linearized prokaryotic expression pPROEX HT (life technologies, USA). The recombinant clones were examined by PCR for the extracted DNA plasmid and the recombinant clone was selected. The selected recombinant clones were grown on the LB medium containing ampicillin as antibiotic $(100 \mu \mathrm{g} / \mathrm{ml})$. For gene induction IPTG was added to the bacterial culture after two hours from inoculation time. The culture was grown in incubator shaker over night at $37^{\circ} \mathrm{C}$ with shaking at 200 rpm and the cloning was done according to the protocols outlined by Life Technologies (Invitrogen Company, USA). For that reason the study aimed to design another primers to amplify the lectin full length gene and use it in this case with the 5 and 3 race RNA synthesis kit (SMARTer ${ }^{\mathrm{TM}}$ RACE CDNA Amplification Kit, Clonetech Company, USA).

Examination of gene function

Lectin purification using $6 x$ histidine affinity-tagged method

Lectin purification was carried out by Ni-NTA resin matrix (QIAGEN Inc., USA). The induced bacterial cells was pelleted and re-suspended in 4 volumes of lysis buffer $(50 \mathrm{mM}$ Tris- $\mathrm{HCl}$ (pH 8.5 at $\left.4^{\circ} \mathrm{C}\right), 5 \mathrm{mM}$ 2-mercaptoethanol, $1 \mathrm{mM}$ PMSF). The suspension was sonicated until $80 \%$ of the cells were lysed. The cell debris was removed by centrifugation; the supernatant was removed to a new tube (crude supernatant). Affinity purification was done according to the protocols outlined by Life Technologies, Invitrogen.

\section{Solublization and renaturation of lectin protein}

The inclusion pellets were solubilized in $8 \mathrm{M}$ urea buffer $(\mathrm{pH}$ 8) as per the procedures developed by [18]. The urea mixture was incubated at $25^{\circ} \mathrm{C}$ for $1 \mathrm{~h}$ before the insoluble molecules were removed by centrifugation. The urea solution was then diluted in a high $\mathrm{pH}$ buffer ( $\mathrm{pH}$ 10.7) for renaturation of lectin. After solublization in $8 \mathrm{M}$ urea, the inclusion body solution was diluted with phosphate buffer $\mathrm{pH} 10.7$, the solution was incubated at $25^{\circ} \mathrm{C}$ for $1 \mathrm{~h}$, then pH adjusted to 8 and incubation was continued at $25^{\circ} \mathrm{C}$ for $1 \mathrm{~h}$. The solution was transferred to dialyze against buffer $(20 \mathrm{mM}$ Tris- $\mathrm{HCl}$ pH 8.0, $50 \mathrm{mM} \mathrm{NaCl}$, $1 \mathrm{mM} \mathrm{EDTA}$ ) at $4^{\circ} \mathrm{C}$ overnight.

\section{Hybridization using the $400 b p$ as a probe}

The small DNA fragment (400bp) was used as a probe to detect the lectin gene in the $800 \mathrm{bp}$ amplicones. The DIG System Nonradioactive and Highly Sensitive Detection of Nucleic Acids (Roche Applied Science, Germany) were used according to the manufacture procedures. The large fragment was purified from the agarose gel using agrose DNA extraction 
Ayyub Patel, Biochemical Compounds 2014,

kit (QIAgene, Germany) and the purified DNA was subjected to PCR amplification using the same conditions above. The PCR product was Cloned using T/A based cloning protocol by using TOPO TA Cloning ${ }^{\circledR}$ (with pCR ${ }^{\circledR}$ 2.1-TOPO ${ }^{\circledR}$ Cloning vector) and (a TOP $10 \mathrm{E}$-coli strain) (Invitrogen ${ }^{\mathrm{TM}}$, USA). The recombinant plasmid was screened using white/blue method and the plasmid DNA examined with the same primers (lectin primers).

\section{SDS-PAGE for the recombinant lectin}

The purified lectin was separated on $12 \%$ polyacrylamide gel according to [23]. $10 \mu$ l of the purified protein was loaded and the gel was left for running at 80 Volt for two hours. Staining and destining was performed and the gel was photographed.

\section{Results}

Hybridization using the $400 \mathrm{bp}$ as a probe

The results revealed that amplicone with $800 \mathrm{bp}$ were obtained as shown in (Figure 2). The gel indicated as (Figure 2) was transferred into Nylon membrane and then exposed to prehybridization solution, hybridization solution which contains the $400 \mathrm{bp}$ as probe and then the membrane was exposed to color reaction. The results showed that, negative reaction was obtained. Based on the obtained results, we can conclude that the large fragment was not lectin gene but may be another gene.

The results presented in Figure 3 revealed that two amplicones with different molecular sizes were amplified. The first amplicone was in molecular weight $400 \mathrm{bp}$ but the other one

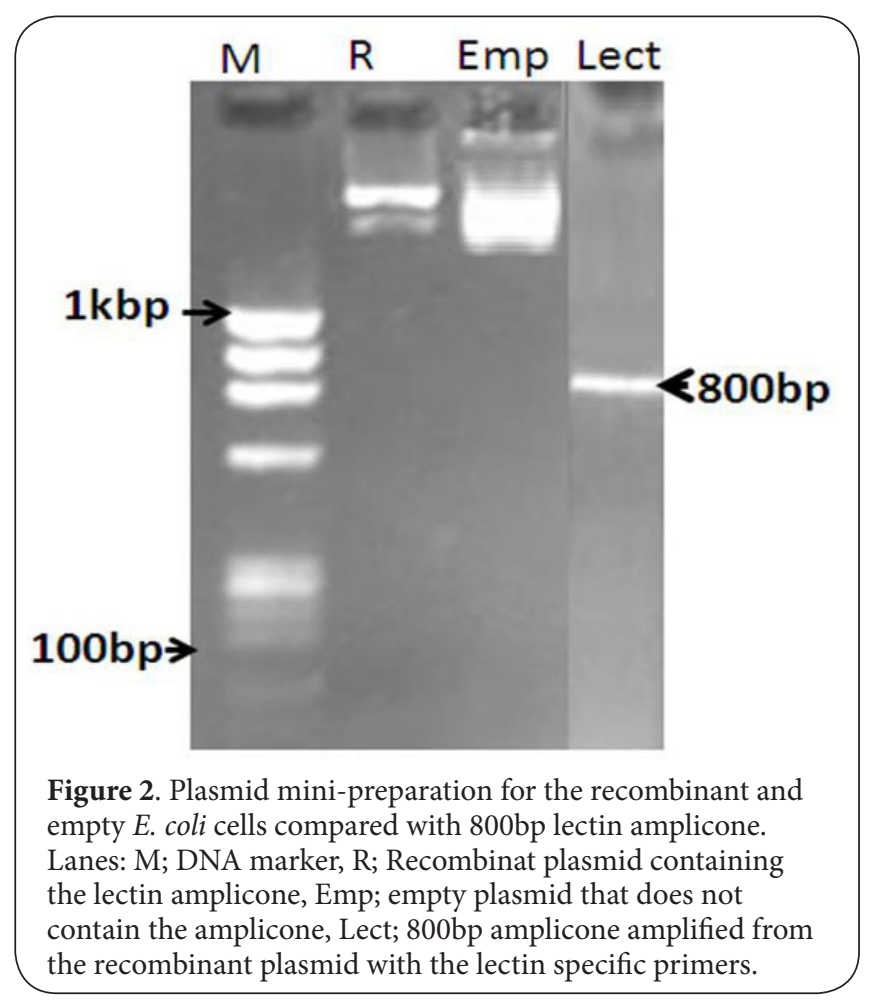

was in molecular weight of about $800 \mathrm{bp}$. Different annealing temperatures were examined to diminish the $400 \mathrm{bp}$ from the $P C R$ reaction but nothing happened. For that reason we expected that the 400bp amplicone may be another copy from lectin gene.

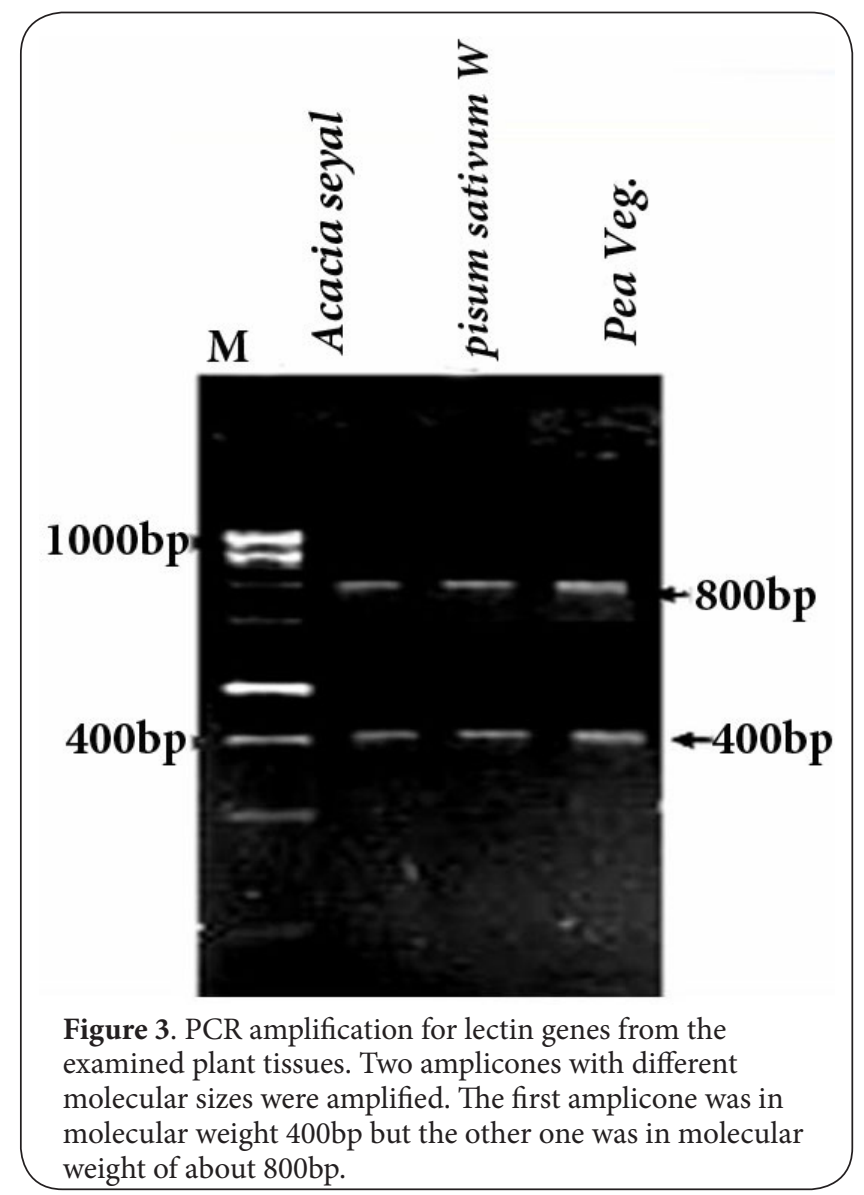

Sequence and sequence analysis

The sequence analysis using BLASTn revealed that the lectin gene isolated from Pisum sativum (wild plant) was similar to the Pisum sativum lect 1 with an identity of $90 \%$. However, the lectin isolated from Pissum (cultivated) showed a similarity of $91 \%$. On the other hand, Acacia lectin showed similarity with Lotus japonicus nod factor binding lectin gene with identity of $95 \%$. It is well known that, if the identity between two genes is not more than $97 \%$, then the examined gene is a new gene. It could be concluded that the three obtained genes are new genes (Figure 4).

\section{Sequence alignment between the three obtained lectin genes}

Results presented in (Figure 5) revealed that the similarity between the lectin gene of the Pisum wild plant and the cultivated Pisum was $95 \%$. The similarity between the wild Pisum and Acacia was $50 \%$ and it was $52 \%$ with the cultivated 
Ayyub Patel, Biochemical Compounds 2014,

http://www.hoajonline.com/journals/pdf/2052-9341-2-2.pdf

Lectin sequence Pisum sativum wild type (Lectin PW)

AAACCTAATCTTGCAAGGAGCTGGCTACACGACAAAAGAGAAGCTGACACTGACCAAGG CTGTAAAGAACACTGTTGGCCGAGCTCTCTATTCCTTACCAATCCCATATCTGGGATAG CGAAACAGGCAACGTTGCTGATTTTACAACTACCTTCATTTTTGTCATAGATGCACCCA ACGGCTACAACGTTGCCGACGGGTTTACGTTCTTCATCGCACCTGTAGATTCTAAAGCC GCAAACCGGCGGTGGATATCTCGGAGTTTTCAATGGCAAAGATTATCCCCGACAAAACT GCTCAAACTGTTGCTGTTGAGTTTGACACTTTCTATAACGCTGCTTGGGATCCAAGCAA CGGAAAGAGACATATTGGAATCGGTGTGA

\section{Lectin Pisum sativum vegetable (Lectin PV)}

ССTTAACCTTAAGGCCAAGGAGGTGGCTACACCACAAAAGAGAAGCTGACACTGACCAA GGCTGTAAAGAACACTGTTGGCCGAGCTCTCTATTCCTTACCTATCCATATCTGGGATA GCGAAACAGGCAACGTTGCTGATTTTACAACTACCCCCTTCATTTTTGTCAAATAGATG CACCCAACGGCTACAACGTTGCCGACGGGTTTACGTTCTTCATCGCACCTGTAGATACT AAGCCGCAAACCGGCGGTGGATATCTCGGAGTTTTCAATGGCAAAGATTATGACAAAAC TGCTCAAACTGTTGCTGTTGAGTTTGACACTTTCTATAACGCTGCTTGGGATCCAAGCA ACGGAAAGAGACATATTGGAATCGGTGTGA

\section{$\underline{\text { Lectin of Acacia seval (Lectin AC) }}$}

CCATGAACGATACGCTGCTAATCCTGAAGAAGCTGCAGAATCTCTGATTCCACTTCTAA AAGAAGCAGAAAATGTGGTTCCTGTGAGCCAGCAACCCAACACACCCGTTAAGCTTGGG GCAACTGCAGGTTTAAGGCTTTTGGAGGGGAATGCTGCTGAAAATATATTGCAAGCGGT CGGGGATATGCTTTCAGCAACAGAAAAAGTGCCCTTGATGCAGTATCTATTCTTGATGG AACCCAAGAAGGTTCTTATCTTTGGGTGACAATTAACTATCCCCTCTTGGGGAAGTTGG GAAAAAGATTTACAAAGACAGTGGGAGTAGTTGATCTAGGAGGTGGGTCAGTGCAAATG ACATATGCAGTCTCAAGGAACACAGCTAAAAATGCTCCTAAG

Figure 4. The DNA nucleotide sequence for the three amplified lectin genes from the three examined plants. ones. On the other hand data presented in (Figures 5 and 6) revealed that when the alignment was performed based on the deduced amino acids, the same identity was obtained between the two Pisum (Wild \& cultivated) plants but the similarity between the two Pisum and Acacia was decreased into 37 and 39\% in successive manner.

The phylogenetic tree for the three obtained lectin genes (Figures 6 and 7) revealed that, the three examined lectins were divided into two different groups but they have the same ancestor. Group 1 contains the two Pisum lectins but group two contains only the Acacia lectin. It could be concluded that the Pisum lectin was completely different from Acacia lectin. Moreover, the obtained DNA sequence is completely new. When the three obtained lectins were compared with the other lectins presented on the data base of the Gene Bank (Figure 7), it was observed that the two lectins of Pisum were closely related to other Pisum and Vicia faba lectins. However, the Acacia lectin was a new outer group for all the other lectins. For this reason this gene was chosen to be cloned and overexpressed.

\section{Recombinant lectin purification from the transformed E.coli}

The purified lectin was separated on $12 \%$ polyacrylamide gel and the data presented in (Figure 8 ) revealed that, two proteins with molecular sizes of 17 and $15 \mathrm{kDa}$ were observed.

\section{Discussion}

Carbohydrate-binding proteins which agglutinate erythro-

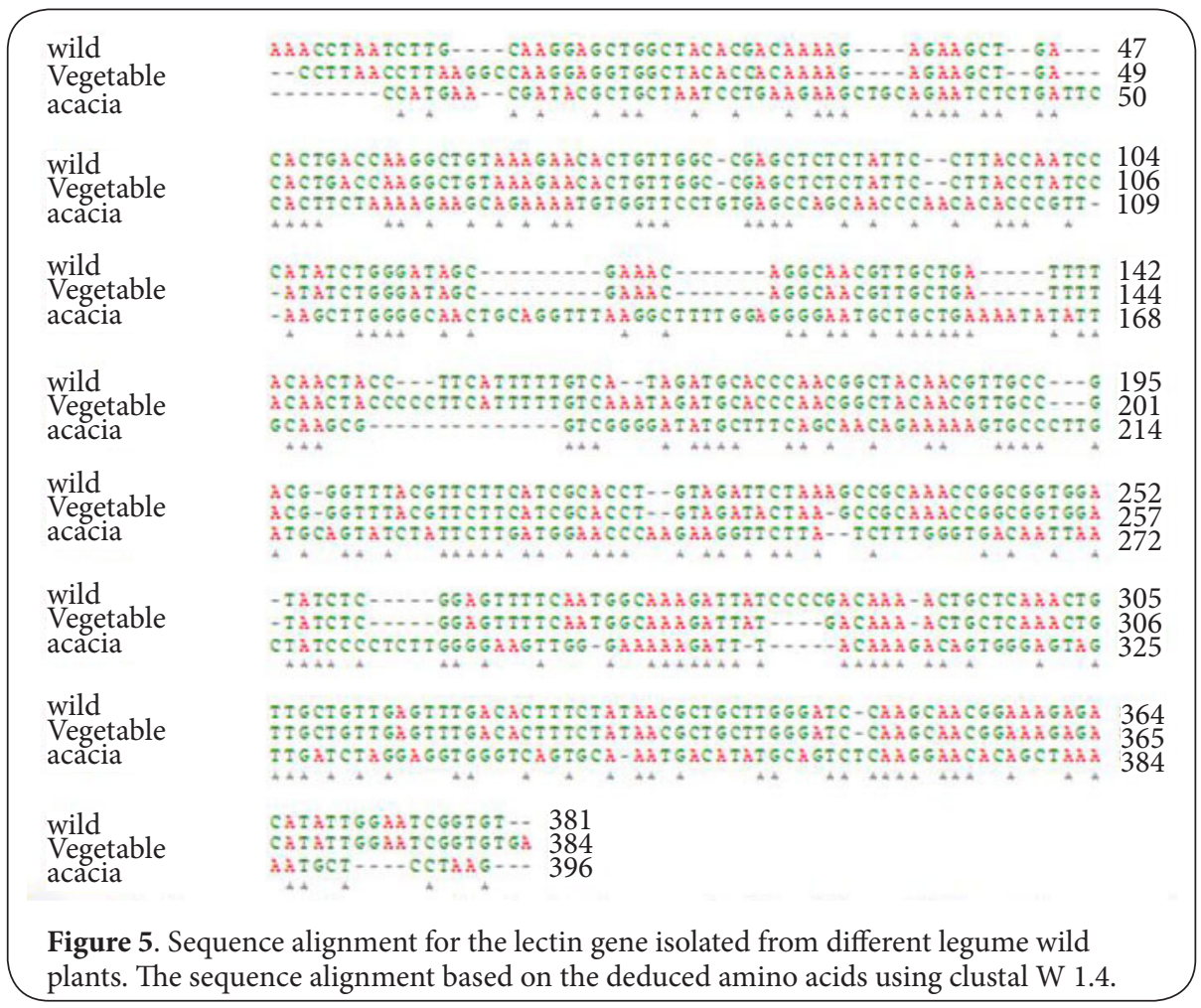




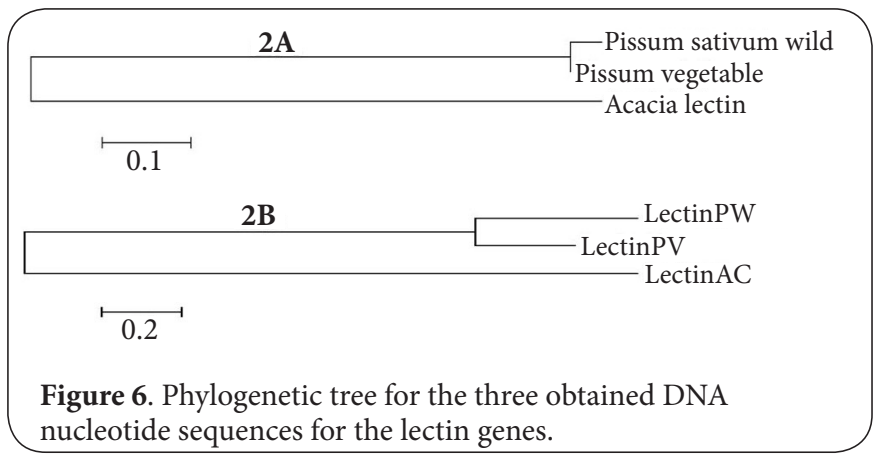

cytes and precipitate glycoconjugates are very common in plant tissues. These phytohaemagglutinins or lectins may be simple proteins or glycoproteins and they exhibit considerable binding specificity towards carbohydrates. The nature and properties of plant lectins have been reviewed by [4]. Leguminous seeds are a rich source of lectins, many of which possess homologous segments of amino acids and, hence, may have an evolutionary relationship [11]. Few examples of enzymes possessing lectin activity have been

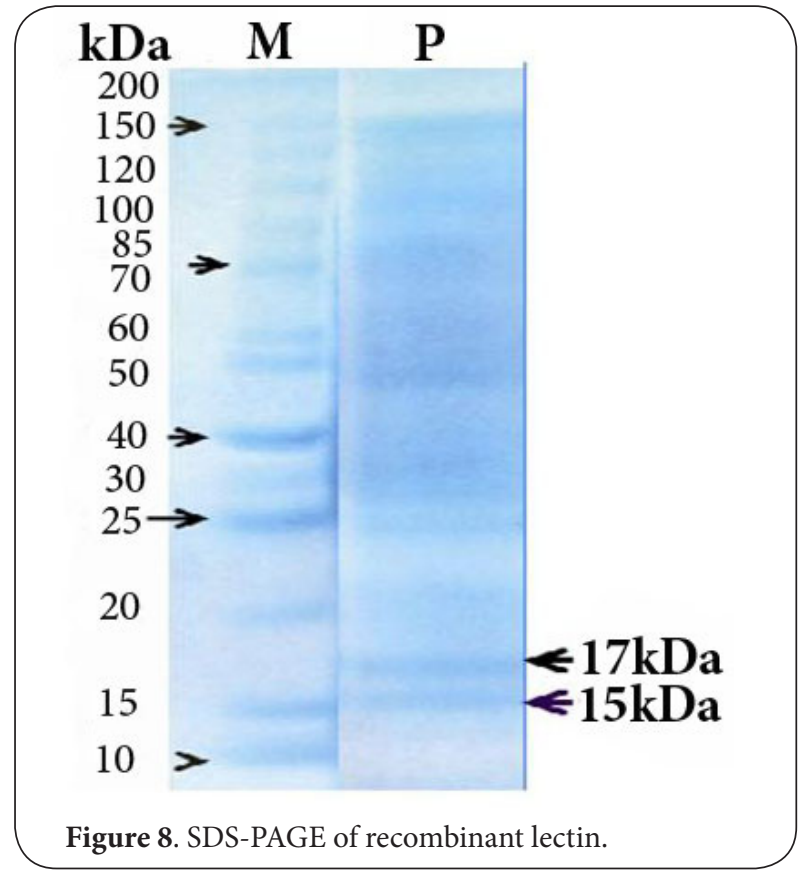

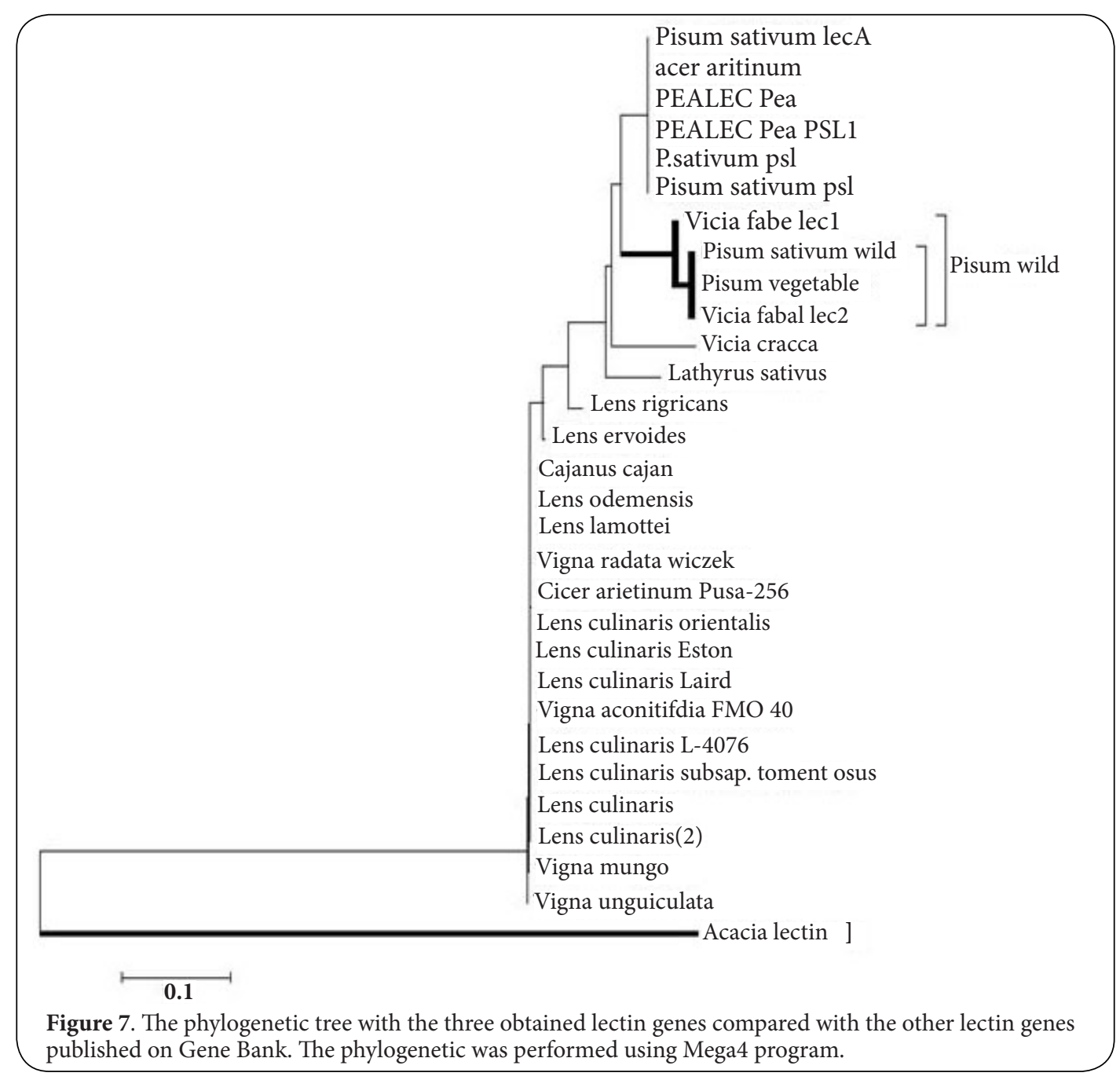


reported but cumannosidase from Phaseolus vulgaris seeds [21] and a-galactosidases obtained from several species of leguminous seeds [6] have been shown to be lectins. Lectin is very important for human health, so the studies aimed to purify and intensify the efficiency of new lectin specially derived from legumes. It is well known that several C-type lectins are present in serum in a soluble form (collectins, galectins, ficolins), where they function as agglutinins and opsonins, promoting phagocytosis by binding to microbial surface carbohydrates. Moreover, Membrane-bound C-type lectins are designed to capture pathogens for intracellular destruction, degradation and antigen loading of major histocompatibility complex molecules, whereas soluble lectins (such as the collectins) function by ligating and opsonizing microorganisms, or might have a role in antigen transport.

Lectins are generally considered to be non-enzymatic and non-immune proteins which selectively bind to a specific carbohydrate structure. The animal lectins are broadly classified into two major categories, the $\mathrm{C}$ type $\left(\mathrm{Ca}^{2+}\right.$-dependent) animal lectins which are structurally related to the asialoglycoprotein receptor while the $S$ type (thiol-dependent) animal lectins form a distinct group which are generally $\beta$-galactoside binding. Embryonic and differentiating tissues of various vertebrates from teleosts, to amphibians, birds and mammals, contain a $\beta$-D-galactoside binding lectin that agglutinates trypsinized rabbit erythrocytes and is specifically inhibited by $\beta$-o-galactopyranosyl $\beta$-D-thiogalactopyranoside and lactose. The major $\beta$-galactoside binding lectin occurring in vertebrate tissues is a dimer with a subunit mass of about $14 \mathrm{kDa}$ and requires thiol but not divalent metal ions for its haemagglutination activity, and exhibits considerable sequence homology among various species [20]. As in (Figure 8) the mass of lectin protein isolated are 15 and $17 \mathrm{kDa}$. Besides the $14 \mathrm{kDa}$ lectin, other $\beta$-galactoside binding lectins have been found in mammalian tissues which include sheep, goat and buffalo liver having molecular weights of 18,22 and 24 $\mathrm{kDa}$, respectively [2]. Of these three $\beta$-galactoside binding hepatic lectins, only sheep lectin required 2 -mercaptoethanol for its haemagglutination activity; in addition it requires $\mathrm{Ca}^{2+}$. In contrast to major soluble $\beta$-galactoside specific lectins, goat and buffalo soluble hepatic lectins show haemagglutination activity against trypsinized rabbit red blood cells only in the presence of $\mathrm{Ca}^{2+}, \mathrm{Mg}^{2+}, \mathrm{Mn}^{2+}, \mathrm{Ni}^{2+}$ or $\mathrm{Sr}^{2+}$ [2] thus differing significantly in cofactor requirement from the known major mammalian $\beta$-galactoside specific lectins. We thus find it important to confirm the presence of a metal binding site of these lectins.

A new recombinant lectin, in a soluble form within $E$. coli cells has been recovered and purified as in (Figure 8 ) In contrast, the recombinant lectin from pea formed insoluble aggregates [26]. The sequence analysis using BLASTn revealed that the lectin gene isolated from Pisum sativum (wild plant) is similar to the Pisum sativum lect 1 with identity $90 \%$. While, the lectin isolated from Pissum (cultivated) showed similarity of $91 \%$. On the other hand, Acacia lectin showed similarity with Lotus japonicus nod factor binding lectin gene with identity of $95 \%$. Results presented in (Figure 6) revealed that the similarity between the lectin gene of the Pisum wild plant and the cultivated Pisum was $95 \%$. While, the similarity between the wild Pisum and Acacia was $50 \%$ but it was $52 \%$ with the cultivated ones. On the other hand data presented in (Figures 6 and 7) revealed that when the alignment was performed based on the deduced amino acids, the same identity was obtained between the two Pisum (Wild \& cultivated) plants but the similarity between the two Pisum and Acacia was decreased into 37 and $39 \%$ in successive manner. Furthermore, the phylogentic tree for the three obtained lectin genes (Figures 6 and 7) revealed that, the three examined lectins were divided into two different groups but they have the same ancestor (0.1 clade). Group 1 contains the two Pisum lectins but group two contains only the Acacia lectin. It could be concluded that the Pisum lectin was completely different from Acacia lectin.

Moreover, the obtained DNA sequence is completely new. When the three obtained lectins were compared with the other lectins presented on the data base of the Gene Bank (Figure 7), it was observed that the two lectins of Pisum were closely related to other Pisum and Vicia faba lectins. However, the Acacia lectin was a new outer group when compared with all the other lectins. For this reason this gene was chosen to be cloned and overexpressed. The recombinant clones were examined by PCR for the extracted DNA plasmid and the recombinant clone was selected. The Recombinant lectin purification from the transformed E.coli showed that the purified lectin is composed of two proteins with molecular sizes 17 and $15 \mathrm{kDa}$ as depicted in (Figure 8). The molecular weights are different from the other recorded before. These new recombinant lectin proteins encourage us to study their cytotoxicity as anticancer agent. Other legume lectins also exhibit antiproliferative activity towards cancer cell lines [30]. The cytotoxicity of the recombinant lectin was performed on breast cancer (MCF-7) cells, liver cancer (HepG-2) cells, and layrnx cancer (HEP-2) and colon cancer (HCT-116) cells. The cytotoxicity of the purified lectin was assayed by a cell viability assay, in the presence of different concentrations of the lectin compounds for 24 $\mathrm{h}$ (the two fractions). Under these experimental conditions, lectin exhibited a significant cytotoxic effect on all cell lines (Ayyub et al., unpublished work). Mitogenic lectins have a curative potential. They may provide protection and recovery from the immunosuppressive and mycelosuppressive effects of tumors and infections. They may also be used against malignancies [28]. Based on the IC50 for the 4 examined cell lines, both liver (HepG-2) and the Lung cancer (Hep-2) were treated with the IC50 of each and incubated at the previous conditions for 48 hours. Samples were taken after 24 and 48 hours in respective manner. The results revealed that the samples treated with lectin showed to be more effective as chemotherapeutic agents for cancer (Based upon further studies by the author and published elsewhere, [3] 
Ayyub Patel, Biochemical Compounds 2014,

Aseer region, in the southern region of Saudi Arabia, is at an altitude of about 2000 feet from the sea level and has its own confidential flora. With regard to the type I C-type lectins, there is evidence that macrophage mannose receptor is associated with a signal transduction pathway leading to tumour necrosis factor (TNF) and interleukin-12 production [9]. No such findings have yet been reported for the recombinant lectin from Pisum sativum (wild plant), Pisum sativum lect1 and Acacia. Hence, the author of this paper has carried our further studies with these recombinant lectins [3] and the results indicated that the expression of the investigated genes was increased in the cells treated with the Doxirbicin. But the expression was mostly the same in the hepatocarcinoma cells but lower in the breast cancer cells treated with lectin. This means that the expression of the TNF was inhibited/suppressed in the breast cancer cells rather than the HepG-2. The expression of the IL-12 was increased in the treated cells with two drugs and the expression was higher in case of hepatocarcinoma more than the breast cancer cell lines. This mean that the immune system was induced when treated with the two examined drugs to resist the cancer effect. In case of the Bcl-2, the expression of this gene was increased with cells treated with doxorubicin compared with the non-treated ones. On the other hand this expression was lower in the cells treated with lectin. This means that presence of lectin make more suppression for the $\mathrm{BCl}-2$ when compared with the doxorubicin. These results assure that the lectin is more effective than the Doxirbicin in the treatment of cancer.

\section{Conclusion}

Lectins isolated from Acacia and Pissum had variance in their identity from the other identified ones in genbank. This study introduces new recombinant lectins ( 15 and $17 \mathrm{kDa}$ ) in that can be used in treatment of cancer, as per our further studies using these recombinant lectins. The lectin is more effective than a widely used anticancer doxorubicin treating different kinds of cancer.

\section{Competing interests}

The author declares that he has no competing interests.

\section{Acknowledgement}

The authors are indebted to the Deanship of Scientific

Research, King Khalid University for financial

support of this project (kku-med.-11/015).

\section{Publication history}

Editor: Monica Butnariu, Banat's University of Agricultural Sciences and Veterinary Medicine, Romania.

Received: 23-May-2014 Final Revised: 13-Jun-2014

Accepted: 16-Jun-2014 Published: 27-Jun-2014

\section{References}

1. Akinsulire OR, Aibinu IE, Adenipekun T, Adelowotan T and Odugbemi T. In vitro antimicrobial activity of crude extracts from plants Bryophyllum pinnatum and Kalanchoe crenata. Afr J Tradit Complement Altern Med.
2007; 4:338-44. | PubMed Abstract | PubMed Full Text

2. Ali $\mathrm{N}$ and Salahuddin $\mathrm{A}$. Isolation and characterization of soluble betagalactoside-binding lectins from mammalian liver. Biochim Biophys Acta. 1989; 992:30-4. | Article | PubMed

3. Ayyub Patel, Elsayed Hafez, Fahmy Elsaid and Mohammed Amanullah. Anti-cancer action of a new recombinant lectin produced from Acacia species. J Med and Medic Sci. 2014; 5:1-11. | Article

4. Bog-Hansen TC. (ed.) Lectins: Biology, Biochemistry and Clinical Biochemistry. Walter de Gruyter, Berlin, New York. 1981; 1.

5. Chandra NR, Ramachandraiah G, Bachhawat K, Dam TK, Surolia A and Vijayan M. Crystal structure of a dimeric mannose-specific agglutinin from garlic: quaternary association and carbohydrate specificity. $J \mathrm{Mol}$ Biol. 1999; 285:1157-68. | Article | PubMed

6. Hankins $\mathrm{CN}$, Kindinger JI and Shannon LM. Legume alpha-Galactosidases Which Have Hemagglutinin Properties. Plant Physiol. 1980; 65:618-22. | Article | PubMed Abstract | PubMed Full Text

7. Chen $J$ and Adams MJ. A universal PCR primer to detect members of the Potyviridae and its use to examine the taxonomic status of several members of the family. Arch Virol. 2001; 146:757-66. | Article | PubMed

8. Fu Y and Li J. Extraction and isolation of the protein groups with anti-tumor activity from Pinellia ternata. Chinese J Inform TCM. 2007; 14:45-46| Article

9. Garner RE, Rubanowice K, Sawyer RT and Hudson JA. Secretion of TNF-alpha by alveolar macrophages in response to Candida albicans mannan. J Leukoc Biol. 1994; 55:161-8. | Article | PubMed

10. Hamelryck TW, Loris R, Bouckaert J, Dao-Thi MH, Strecker G, Imberty A, Fernandez E, Wyns L and Etzler ME. Carbohydrate binding, quaternary structure and a novel hydrophobic binding site in two legume lectin oligomers from Dolichos biflorus. J Mol Biol. 1999; 286:1161-77. | Article I PubMed

11. Hankins CN, Kindinger JI and Shannon LM. Legume Lectins: I. Immunological Cross-Reactions between the Enzymic Lectin from Mung Beans and other Well Characterized Legume Lectins. Plant Physiol. 1979; 64:104-7. | Article | PubMed Abstract | PubMed Full Text

12. Herre J, Willment JA, Gordon S and Brown GD. The role of Dectin-1 in antifungal immunity. Crit Rev Immunol. 2004; 24:193-203. | Article | PubMed

13. Khan F, Ahmad A and Khan MI. Purification and characterization of a lectin from endophytic fungus Fusarium solani having complex sugar specificity. Arch Biochem Biophys. 2007; 457:243-51. | Article | PubMed

14. Lin P and Ng TB. Preparation and biological properties of a melibiose binding lectin from Bauhinia variegata seeds. J Agric Food Chem. 2008; 56:10481-6. | Article | PubMed

15. Liu B, Bian HJ and Bao JK. Plant lectins: potential antineoplastic drugs from bench to clinic. Cancer Lett. 2010; 287:1-12. | Article | PubMed

16. Liu B, Zhang B, Min MW, Bian HJ, Chen LF, Liu Q and Bao JK. Induction of apoptosis by Polygonatum odoratum lectin and its molecular mechanisms in murine fibrosarcoma L929 cells. Biochim Biophys Acta. 2009; 1790:840-4. | Article | PubMed

17. Maltas E, Dageri N, Vural HC and Yildiz S. Biochemical and molecular analysis of soybean seed from Turkey. Journal of Medicinal Plants Research. 2011; 5:1575-1581. | Article

18. Marston FA, Lowe PA, Doel MT, Shoemaker JM, White S and Angal S. Purification of calf prochymosin (prorennin) synthesized in Escherichia coli. Biotechnology (N Y). 1984; 2:800-804. | Article

19. Park WB, Han SK, Lee MH and Han KH. Isolation and characterization of lectins from stem and leaves of Korean mistletoe (Viscum album var. coloratum) by affinity chromatography. Arch Pharm Res. 1997; 20:30612. | Article | PubMed

20. Paroutaud P, Levi G, Teichberg VI and Strosberg AD. Extensive amino acid sequence homologies between animal lectins. Proc Natl Acad Sci U S A. 1987; 84:6345-8. | Article | PubMed Abstract | PubMed Full Text

21. Paus $E$ and Steen HB. Mitogenic effect of alpha-mannosidase on lymphocytes. Nature. 1978; 272:452-4. | Article | PubMed 
Ayyub Patel, Biochemical Compounds 2014,

22. Rubinstein N, Ilarregui JM, Toscano MA and Rabinovich GA. The role of galectins in the initiation, amplification and resolution of the inflammatory response. Tissue Antigens. 2004; 64:1-12. | Article | PubMed

23. Sambrook, Joseph; Russell and David W. Molecular cloning : a laboratory manual, 3rd ed. Cold Spring Harbor Laboratory, New York. 2001.

24. Santi-Gadelha T, Rocha BA, Oliveira CC, Aragao KS, Marinho ES, Gadelha CA, Toyama MH, Pinto VP, Nagano CS, Delatorre P, Martins JL, Galvani FR, Sampaio AH, Debray H and Cavada BS. Purification of a PHA-like chitin-binding protein from Acacia farnesiana seeds: a time-dependent oligomerization protein. Appl Biochem Biotechnol. 2008; 150:97-111. | Article | PubMed

25. Seufi AM, Hafez EE and Galal FH. Identification, phylogenetic analysis and expression profile of an anionic insect defensin gene, with antibacterial activity, from bacterial-challenged cotton leafworm, Spodoptera littoralis. BMC Mol Biol. 2011; 12:47 | $\underline{\text { Article | PubMed }}$ Abstract | PubMed Full Text

26. Stubbs ME, Carver JP and Dunn RJ. Production of pea lectin in Escherichia coli. J Biol Chem. 1986; 261:6141-4. I Article I PubMed

27. Sun GX, Ding S and Qian YJ. The extraction and chemical analysis of proteins from Pinellia pedatisecta and their inhibitory effects on the mouse Sarcoma-180. J Shanghai Med. 1992; 19:17-20 | Article

28. Wimer BM. Curative potential of foremost mitogen applications. Cancer Biother Radiopharm. 2003; 18:903-16. | Article | PubMed

29. Wong JH and $\mathrm{Ng} \mathrm{TB}$. Isolation and characterization of a glucose/ mannose/rhamnose-specific lectin from the knife bean Canavalia gladiata. Arch Biochem Biophys. 2005; 439:91-8. | Article | PubMed

30. Wong JH and Ng TB. Purification of a trypsin-stable lectin with antiproliferative and HIV-1 reverse transcriptase inhibitory activity. Biochem Biophys Res Commun. 2003; 301:545-50. I Article I PubMed

31. Yan Q, Li Y, Jiang Z, Sun Y, Zhu L and Ding Z. Antiproliferation and apoptosis of human tumor cell lines by a lectin (AMML) of Astragalus mongholicus. Phytomedicine. 2009; 16:586-93. | $\underline{\text { Article | PubMed }}$

32. Zhu MW, Zheng K and Ding SS. Total proteins of pinellia pedatisecta effects in ovarian cancer cell lines and in human umbilical cord blood hematopoietic progenitors. J Shanghai Med. 1999; 26:455-458.

\section{Citation:}

Patel A. Isolation, characterization and production of a new recombinant lectin protein from leguminous

plants. Bio Chem Comp. 2014; 2:2.

http://dx.doi.org/10.7243/2052-9341-2-2 